\title{
MINERALOGY AND PETROLOGY OF KIMBERLITE FROM WEMINDJI, QUEBEC
}

\author{
Roger H. Mitch ell ${ }^{1}$ and Jacqu es Letendre ${ }^{2}$ \\ ${ }^{1}$ Lakehead University Thunder Bay, Ontario; ${ }^{2}$ Majescor Resources, Montreal, Quebec
}

\section{INTRODUCTION}

Exploration by Majescor Resources in the Wemindji area of Northern Quebec has resulted in the discovery of several sub-horizontal sills of kimberlite emplaced in a granitic-gneiss terrain.

The Wemindji kimberlites occur as thin dike/sill-like bodies, ranging from about $8 \mathrm{~cm}$ to 1 meter in thickness, in vertical drill core samples. They exhibit an extremely wide variation in their macroscopic appearance, ranging from fine grained macrocryst-free aphanitic dolomitic hypabyssal kimberlite to ilmenite/garn et macrocryst-dominated hypabyssal kimberlite. Flow differentiation features and multiple intrusion within a given dike/sill are characteristic. Regardless of the extreme macroscopic and microscopic variation in mode and texture, the kimberlites are all simply variants of single mineralogical type of kimberli te; namely macr ocrystal spin el-ilmen ite-apatitephlogopite-dolomite hypabyssal kimberlite. Crater- and diatreme facies kimberlites are not present.

\section{Macroscopic Character}

Macroscopically, the Wemindji kimberlite dikes/sills typically exhibit fine grained macrocryst-free margins and internal crystal size grading. This feature is particularly well-seen in core $02-10$, in which an $8 \mathrm{~cm}$ thick dike is intrusive into granite. At the contacts the fine grained phase is $1 \mathrm{~cm}$ and $0.5 \mathrm{~cm}$ in thickness at the upper and lower margins of the dike, respectively. The bulk of the dike exhibits normal grading with a decrease in the size of olivine macrocrysts from the bottom to the top of the dike. Grading is particularly evident in the macrocryst-rich dike 02-26. Here the bottom portion of the sill contains close-packed ilmenite, garnet andolivine macrocrysts, with gradation upwards into macrocrystal kimberlite contain ing fewer and smaller macrocrysts. In the closely-packed macrocryst-rich portions of this unit the kimberlite matrix comprises less than $10 \%$ of the rock. Other discrete intrusions in the lower composite sill of core 02-09 exhibit similar size grading.
The lower composite sill encountered in core 02-09 also contains (at 15.3 - 15.6m) multiple thin units of fine-grained carbonate-rich aphanitic hypabyssal kimberlite. Individual bands range from $0.25-1 \mathrm{~cm}$ in thickness, and differ modally with respect to the opaque mineral to carbonate ratio. Thin black bands (0.1$0.2 \mathrm{~mm}$ ) of oxide-rich material are common within this unit. Erosional contacts between modally-different bands of kimberlite within composite sills are commonly found. Because of the extreme modal variation between and within sills It is not possible to correlate intrusions between the various drill holes.

Small $(<1 \mathrm{~cm})$ xen oliths of gra nite, ph logopitepyroxenite, and harzburgite occur within the sills. The upper portion of core 02-26 (from 22.70-23.20m) contains many such xen oliths. A large $(4 \mathrm{~cm})$ rounded harzburgite xenolith occurs at $23.2 \mathrm{~m}$ in th is core. Reactions of the kimberlite with the host granitic rocks range from none to bleaching and chloritization.

All of the diverse macroscopic text ural features result from flow differentiation of very fluid, low viscosity carbonate-rich kimber lite. Unusual aspects of the Wemindji kimberlites are: (1) the presence of complex, composite, flow-differentiated dikes/sills; (2) the exceptional concentration of large $(1-2 \mathrm{~cm})$ macrocrysts in some of the sills. With regard to the latter, such macrocryst-rich kimberlites are rare, one notable example occurring in one of the kimberlite units at the Monastery Mine (RSA). Flow differentiated carbonaterich sills are known from the Benfontein and Wesselt on Mines (RSA). These intrusion s have many similarities with the Wemindji sills, in particular the flowdifferentiation, "graded bedding", an d erosional features. Unlike the Wemindji sills they are characterized by diapiric segregations of carbonate. Although carbonate segregations are present in the Wemindji sills they tend to be small, irregular and elongated by flow. 


\section{Petrographic Character Macrocrysts}

Angular xenocrysts of quartz are common in many samples. These do not exhibit any reaction margin s. Olivine is the domin ant macrocryst in all of the kimberlites. It forms rounded-to-anhedral crystals which can be concentrated by flow differentiation. All macrocrystal olivines are completely pseudomorph ed by pale yellow lizardite. Typically, the olivines contain at their margins many small subhedral-to-euhedral crystals of deep red rutile. Such inclusions are absent from the cores of the grains suggesting that originally the macrocrystal olivines possessed mantles of a different composition, i.e. similar to that of the groundmass olivine (see below). Some macrocrystal olivines have been replaced by quartz plus serpentine. This style of pseudomorphing is evident in the thin contaminated sill occurring at $12.5-13.0 \mathrm{~m}$ in core 02-09. Despite the abundance of carbonate in these rocks prograde pseudomorphing by carbonate is rare.

Many of the kimberl ites contain irregu lar plates of colourless-to-pale orange pleochroic phlogopite. Typically these are altered along cleavage planes to gr een chlorite.

Magnesian ilmenite occurs as rounded macrocrysts up to $2 \mathrm{~cm}$ in size in cores 02-22 and 02-26. Typically, these are single crystals but mosaic-textured examples also occur. In terms of their composition they contain from 7 - 13 wt. $\% \mathrm{MgO}$ and $<2$ wt. $\% \mathrm{Cr}_{2} \mathrm{O}_{3}$. Magnesian ilmenite also occurs as irregular microcrysts throughout the groundmass of the kimberlites (Table 3) These can contain up to $23 \mathrm{wt} . \% \mathrm{MgO}$ and are typically mantl ed by either pure ilmenite, $\mathrm{Mn}-\mathrm{Nb}$-ilmenite (Table 3 ) and more rarely by spinel.

Garnets are common in cores 02-22 and 02-26. They are rounded and/or elongated and have welldeveloped kelyphitic rims consisting of mica and spinel. The crystals analysed were low $\mathrm{Ti}$, low chrome (2-3 wt. $\% \mathrm{Cr}_{2} \mathrm{O}_{3}$ ) pyrope (i.e. $\mathrm{G} 1 / \mathrm{G} 9$ garnets). In core $0-26$, fresh orthopyroxene is common as large rounded macrocrysts.

\section{Groundmass}

In addition to olivine and magnesian ilmenite microcrysts the groundmass is composed of: microphenocrystal olivine, spinel, ilmenite, $\mathrm{Mn}-\mathrm{Nb}$ ilmenite, rutile, apatite, phlogopite - barian phlogopite, baddeleyite, REE-phosphate, serpentine, calcite and dolomite.

Microphenocrystal olivine forms small euhedral-to-subhedral crystals. The majority of the crystals are now complet ely pseud omorphed by lizar dite.
Typically the crystals contain randomly-orientated inclusions of deep red rutile. Similar inclusions occur in the outer margins of the olivine macrocrysts suggesting that the latter have been mantled by olivine of the type which forms the microphenocrysts. Rarely olivine is replaced by dolomite and apatite. Relict olivines (Table 1) are typically uniform in composition with Mg\#'s of $0.89-0.91$, rarelyirregular cores of $\mathrm{Mg}$-rich material are found (Mg\# 0.93).

Spinel occurs as euhedral-to-subhedral opaque crystals 5 - 60 microns in size. The majority of the bonafide groundmass spinels are Cr-poor members of the qandilite (magnesian ulvöspinel) - ulvöspinel magnetite series with significant contents of $\mathrm{MgAl}_{2} \mathrm{O}_{4}$ spinel (10 14 mol.\%). (Table 1). The qandilite content can range from 20 - 50 mol. $\mathrm{Mg}_{2} \mathrm{TiO}_{4}$. Individual sills contain spinels of differing composition. Discrete, anhedral Crrich relict cores are rarely present. In some samples spinels have relatively $\mathrm{Mg}$-poor, Fe-rich cores which are zoned to $\mathrm{Mg}$-rich, Fe-poor rims, i.e. towards qandilite enrichment. However, typically groundmass spinels are of uniform composition and are Fe-rich. The overall trend of composition al change is from Al-bearing spinels through qandil ite-rich examples to ulvospinel-magnetite and ultimately to magnetite (Table 2). Baddeleyite inclusions are common in the spinels. The spinels have $\mathrm{Fe} / \mathrm{Fe}+\mathrm{Mg}$ ratios of $0.55-0.72, \mathrm{Ti} /(\mathrm{Ti}+\mathrm{Cr}+\mathrm{Al})>0.49$, and $\mathrm{Cr} / \mathrm{Cr}+\mathrm{Al}<0.1$, i.e. they plot of the back face of the reduced spinel prism and follow spinel compositional trend 1. The spinel compositions indicate that these rocks are highly-evolved kimberlites. The presence of a $\mathrm{MgAl}_{2} \mathrm{O}_{4}$ component coupled with very low $\mathrm{Cr}$ suggests that the magma could have been contaminated with $\mathrm{Al}$ derived from the country rocks. Also rarely present are large rounded microcrysts $(<0.5 \mathrm{~mm})$ belonging to the solid solution series $(\mathrm{Fe}, \mathrm{Mg}) \mathrm{Cr}_{2} \mathrm{O}_{4}-\mathrm{Fe}_{3} \mathrm{O}_{4}$ with only small amounts of qandilite $(<6 \mathrm{~mol} . \%)$.

Phlogopite occurs as euhedral zoned microphenocrysts ( $50 \times 25 \mathrm{um}$ ), ragged skeletal microphenocrysts $(20 \mathrm{x}<10 \mathrm{um})$, and fine grained laths $(<5$ um x $1 \mathrm{um})$ in interstices between carbonates. The distribution is very irregular, e.g. some dolomite-rich samples do not contain any phlogopite, whereas other petrog raphically-similar samples contain $10-20$ vol. \% phlogopite. Zoned crystals consist of a rounded discrete core of phlogopite and a euhedral mantle of barian phlogopite (5 - $9 \mathrm{wt} . \% \mathrm{BaO})$, i.e. phlogopite-kinoshitalite solid solutions (Table 2). Different samples contain micas of differing composition.

Ilmenite is common as anhedral-to-subhedral groundmass crystals and as reaction mantles upon magnesian ilmenite microcrysts. This groundmass 
ilmenite (Table 3) is typica lly relatively-pure $\mathrm{FeTiO}_{3}$ with $<1.0$ wt. $\% \mathrm{MgO}$. However, some crystals are enriched in $\mathrm{MnO}$ (up to 12 wt.\%) and $\mathrm{Nb}_{2} \mathrm{O}_{5}$ (3 - 6 wt.\%). Mantles of magnetite occur on some crystals.

Deep red-coloured rutile is comm on as anhedral microcrysts in the groundmass. This mineral is probably derived principally from altered olivine crystals and is strewn throughout the groundmass during the serpentinization process. Typically the crystals are small $(<20 \mathrm{um})$ and of subhedral-to-rounded habit. Niobium contents can range up to $5 \mathrm{wt} . \% \mathrm{Nb}_{2} \mathrm{O}_{5}$.

The major components of the groundmass in which all of the above are set are dolomite and apatite. The former is the principal carbonate found in these rocks and occurs an anhedral interlocking plates. In some samples dolomite is intergrown with calcite. The dolomite contains $<0.5$ wt. $\% \mathrm{FeO}$ or $\mathrm{MnO}$, and the calcite $<0.4$ wt. $\% \mathrm{MgO},<0.2 \mathrm{wt} \% \mathrm{FeO}$ and $\mathrm{MnO}$. Apatite is abundant (10-20 vol.\% in some samples) and forms large late-stage anhedral plates (100 - $200 \mathrm{um})$. Prismatic apatite appears to be absent. The apatite contains minor (1 -2 wt.\%) to significant (10 - $12 \mathrm{wt} . \%)$ amounts of SrO, depending upon sample. In core 02-09 Sr-apatite (5- 10 wt.\%) coexists with abundant late-stage REE-phosphate (25.1 wt. $\% \mathrm{Ce}_{2} \mathrm{O}_{3}, 14.8$ wt. $\% \mathrm{La}_{2} \mathrm{O}_{3}, 13.4$ wt. $\% \mathrm{Nd}_{2} \mathrm{O}_{3}, 2.3$ wt. $\% \mathrm{SrO}, 6$ wt. $\% \mathrm{CaO}, 1.3$ wt. $\% \mathrm{FeO}$, 4.7 wt. $\% \mathrm{SO}_{3}, 25.3$ wt. $\% \mathrm{P}_{2} \mathrm{O}_{5}$. Wemin dji kimberlites are relatively-poor in serpoph itic serpentine although this material is rarely present in the groundmass.

These rocks are unlike most kimberlites in that perovskite does not appear to be present as a groundmass primarymineral. Other minerals which are absent in the section s examined include: melilite and/or its al teration products; andra dite garnet; clin opyroxene; nepheline; pectolite and other calcium silicates.

\section{Concluding Comments}

The Wemindji rocks are dolomite-rich highlydifferentiated hypabyssal kimberlites. In terms of kimberlite nomenclature they range from dolomite spinel kimberlite through macrocrystal dolomite apatite kimberlite to garnet - magnesian ilmenite macrocrystal kimberlite. The diverse modes and textural features result from flow-differentiation and multiple intrusions ofmany batches of genetically-related kimberlite magma. The kimberlites have been contaminated by reactions with country rock prior to their emplacement.
Table 1. Compositions of Olivine

$\begin{array}{lrrrc}\text { wt.\% } & & & & \\ \mathrm{SiO}_{2} & 40.24 & 39.83 & 40.93 & 40.18 \\ \mathrm{FeO}_{\mathrm{T}} & 7.02 & 10.54 & 6.64 & 10.63 \\ \mathrm{MnO} & 0.0 & 0.21 & 0.24 & 0.13 \\ \mathrm{MgO} & 51.12 & 48.46 & 51.39 & 48.11 \\ \mathrm{CaO} & 0.08 & 0.07 & 0.04 & 0.0 \\ & 98.46 & 99.11 & 99.24 & 99.05\end{array}$

Structural formula $(O=4)$

$\begin{array}{lcccc}\mathrm{Si} & 0.99 & 0.99 & 1.00 & 1.00 \\ \mathrm{Fe} & 0.14 & 0.22 & 0.14 & 0.22 \\ \mathrm{Mn} & - & - & - & - \\ \mathrm{Mg} & 1.87 & 1.79 & 1.86 & 1.78 \\ \mathrm{Ca} & - & - & - & - \\ & 3.00 & 3.00 & 3.00 & 3.00 \\ & & & & \\ \mathrm{mg} \# & 0.93 & 0.89 & 0.93 & 0.89\end{array}$


Table 2 Representative Compositions of spinels

\begin{tabular}{lccrrrrrrrrr} 
wt.\% & 1 & 2 & \multicolumn{1}{c}{3} & \multicolumn{1}{c}{4} & 5 & 6 & \multicolumn{1}{c}{7} & \multicolumn{1}{c}{8} & 9 & 10 & 11 \\
$\mathrm{MgO}$ & 9.35 & 10.02 & 15.38 & 21.74 & 18.94 & 14.29 & 10.19 & 7.59 & 3.91 & 1.16 & 0.85 \\
$\mathrm{Al}_{2} \mathrm{O}_{3}$ & 0.92 & 0.50 & 8.46 & 9.51 & 5.28 & 13.04 & 3.12 & 1.83 & 1.28 & 1.75 & 0.43 \\
$\mathrm{TiO}_{2}$ & 8.01 & 6.57 & 16.57 & 18.73 & 18.45 & 18.11 & 14.44 & 13.41 & 14.22 & 14.25 & 0.73 \\
$\mathrm{Cr}_{2} \mathrm{O}_{3}$ & 41.64 & 46.77 & 0.49 & 0.71 & 0.36 & 1.60 & 0.37 & 0.70 & 0.0 & 0.26 & 0.11 \\
$\mathrm{MnO}$ & 0.42 & 0.53 & 0.43 & 0.43 & 0.88 & 0.42 & 0.71 & 0.82 & 0.40 & 0.79 & 0.17 \\
$\mathrm{FeO}_{\mathrm{T}}$ & 40.39 & 34.13 & 56.13 & 46.43 & 52.74 & 57.04 & 67.67 & 71.34 & 74.89 & 76.76 & 89.46 \\
Recalculated Fe & & & & & & & & & & \\
$\mathrm{FeO}$ & 25.23 & 21.96 & 24.14 & 16.67 & 19.20 & 22.89 & 29.06 & 31.37 & 37.77 & 41.66 & 29.81 \\
$\mathrm{Fe}_{2} \mathrm{O}_{3}$ & 16.85 & 13.52 & 35.55 & 33.62 & 37.27 & 34.15 & 43.53 & 44.42 & 41.33 & 39.00 & 66.29 \\
$\mathrm{Total}^{102.42}$ & 99.87 & 101.02 & 101.42 & 100.38 & 101.06 & 99.78 & 100.14 & 98.84 & 98.88 & 98.39 \\
$\mathrm{Mol}_{0} \%$ End membermolecules & & & & & & & & & \\
$\mathrm{MgAl}_{2} \mathrm{O}_{4}$ & 1.53 & 0.87 & 11.35 & 12.19 & 6.90 & 12.02 & 3.34 & 2.60 & 1.88 & 2.63 & 0.66 \\
$\mathrm{Mg}_{2} \mathrm{TiO}_{4}$ & 25.42 & 21.91 & 30.61 & 43.69 & 41.76 & 34.15 & 23.23 & 18.47 & 9.48 & 1.33 & 1.97 \\
$\mathrm{MgCr}_{2} \mathrm{O}_{4}$ & 3.78 & 14.06 & - & - & - & - & - & - & - & - & - \\
$\mathrm{MnCr}_{2} \mathrm{O}_{4}$ & 1.00 & 1.33 & - & - & - & - & - & - & - & - & - \\
$\mathrm{Mn}_{2} \mathrm{TiO}_{4}$ & - & - & 0.62 & 0.59 & 1.24 & 0.40 & 0.92 & 1.25 & 0.63 & 1.28 & 0.16 \\
$\mathrm{FeCr}_{2} \mathrm{O}_{4}$ & 41.52 & 39.27 & 0.44 & 0.61 & 0.32 & 0.29 & 0.26 & 0.67 & - & 0.26 & 0.10 \\
$\mathrm{Fe}_{2} \mathrm{TiO}_{4}$ & - & - & 11.31 & 1.65 & 3.14 & 10.89 & 13.91 & 16.68 & 29.86 & 38.37 & - \\
$\mathrm{Fe}_{3} \mathrm{O}_{4}$ & 26.75 & 22.56 & 45.66 & 41.26 & 46.64 & 42.25 & 56.23 & 60.33 & 58.14 & 56.12 & 97.09
\end{tabular}

1-2 relict chromite-qandilite-magnetite cores; 3-4 core (spinel- ulvospinel-qandilite-magnetite) and rim (spinelqandilite-magnetite) of zoned spinel; 5- 11 isolated euhedral-to-subhedral spinels in core 02-09 illustrating the very wide range in spinel compositions.

Table 3 Representative Compositions of Ilmenite

$\begin{array}{lrrrlrrrr}\text { wt. } \% & 1 & 2 & 3 & 4 & 5 & 6 & 7 & 8 \\ \mathrm{MgO} & 19.30 & 15.73 & 12.87 & 0.30 & 0.60 & 0.13 & 0.15 & 0.12 \\ \mathrm{Al}_{2} \mathrm{O}_{3} & 0.19 & 0.0 & 0.47 & 0.13 & 0.39 & 0.14 & 0.53 & 0.07 \\ \mathrm{TiO}_{2} & 55.00 & 54.61 & 53.21 & 51.15 & 47.91 & 49.46 & 93.48 & 94.37 \\ \mathrm{Cr}_{2} \mathrm{O}_{3} & 1.61 & 2.14 & 0.75 & 0.0 & 3.16 & 0.0 & 0.0 & 0.0 \\ \mathrm{MnO} & 0.59 & 0.69 & 0.27 & 1.17 & 5.26 & 11.18 & 0.0 & 0.10 \\ \mathrm{FeO}_{\mathrm{T}} & 22.51 & 25.70 & 33.23 & 46.60 & 41.50 & 36.30 & 3.76 & 1.48 \\ \mathrm{Nb}_{2} \mathrm{O}_{5} & 0.20 & 1.28 & 0.0 & 0.51 & 0.32 & 2.84 & 0.63 & 2.61 \\ \text { Recalculated Fe }(2 \text { cations/3 } & \text { oxygens) } & & & & \\ \mathrm{FeO} & 14.66 & 21.75 & 24.63 & 44.84 & 37.04 & 36.00 & - & - \\ \mathrm{Fe}_{2} \mathrm{O}_{3} & 8.72 & 4.39 & 9.56 & 1.96 & 4.96 & 0.33 & 4.18 & 1.64 \\ \mathrm{Total}^{2} & 100.27 & 100.59 & 101.76 & 100.06 & 99.64 & 100.08 & 98.97 & 98.91\end{array}$

Mol.\% End Member Molecules

$\begin{array}{lrcccrr}\mathrm{Al}_{2} \mathrm{O}_{3} & 0.25 & - & 0.63 & 0.19 & 0.58 & 0.22 \\ \mathrm{Cr}_{2} \mathrm{O}_{3} & 1.40 & 1.93 & 0.67 & - & 3.17 & - \\ \mathrm{Fe}_{2} \mathrm{O}_{3} & 7.22 & 3.77 & 8.14 & 1.87 & 4.73 & 0.33 \\ \mathrm{Nb}_{2} \mathrm{O}_{5} & 0.10 & 0.66 & - & 0.29 & 0.18 & 1.69 \\ \mathrm{MnTiO}_{3} & 1.10 & 1.33 & 0.52 & 2.52 & 11.30 & 24.89 \\ \mathrm{MgTiO}_{3} & 63.30 & 53.48 & 43.43 & 1.14 & 2.27 & 0.51 \\ \mathrm{FeTiO}_{3} & 26.60 & 38.83 & 46.62 & 93.99 & 77.78 & 72.37\end{array}$

1-3 macrocrystal Mg-ilmenite; 4-6 ilmen ite occurring as mantles upon groundmass spinels an dilmenite macrocrysts; 7-8 rutile. 
Table 4. Representative Compositions of Phlogopite and Barium Phlogopite

\begin{tabular}{|c|c|c|c|c|c|c|c|c|c|}
\hline wt.\% & 1 & 2 & 3 & 4 & 5 & 6 & 7 & 8 & 9 \\
\hline $\mathrm{SiO}_{2}$ & 42.37 & 33.38 & 41.50 & 32.58 & 42.38 & 32.58 & 36.96 & 35.89 & 33.74 \\
\hline $\mathrm{TiO}_{2}$ & 0.0 & 0.97 & 0.0 & 0.33 & 0.90 & 0.25 & 0.40 & 0.59 & 0.63 \\
\hline $\mathrm{Al}_{2} \mathrm{O}_{3}$ & 10.71 & 18.62 & 10.21 & 17.91 & 10.25 & 19.28 & 15.65 & 17.18 & 18.21 \\
\hline $\mathrm{Cr}_{2} \mathrm{O}_{3}$ & 0.12 & 0.08 & 0.81 & 0.09 & 0.19 & 0.11 & 0.22 & 0.21 & 0.07 \\
\hline $\mathrm{FeO}_{\mathrm{T}}$ & 3.59 & 2.00 & 4.72 & 1.55 & 4.74 & 1.65 & 2.82 & 1.83 & 2.25 \\
\hline $\mathrm{MnO}$ & 0.08 & 0.26 & 0.0 & 0.25 & 0.37 & 0.0 & 0.0 & 0.0 & 0.0 \\
\hline $\mathrm{MgO}$ & 27.30 & 24.28 & 27.33 & 23.82 & 25.89 & 25.16 & 26.79 & 25.97 & 24.94 \\
\hline $\mathrm{Na}_{2} \mathrm{O}$ & 0.39 & 0.53 & 0.09 & 0.27 & 0.23 & 0.35 & 0.37 & 0.20 & 0.17 \\
\hline $\mathrm{K}_{2} \mathrm{O}$ & 10.82 & 7.61 & 9.47 & 6.96 & 9.30 & 6.64 & 8.85 & 8.55 & 8.16 \\
\hline $\mathrm{BaO}$ & 0.21 & 8.45 & 0.16 & 10.30 & 0.0 & 12.10 & 4.04 & 5.58 & 6.99 \\
\hline Total & 95.51 & 96.25 & 94.12 & 95.06 & 94.23 & 97.87 & 96.06 & 96.01 & 95.16 \\
\hline \multicolumn{10}{|c|}{ Structural formulae based on 22 atoms of oxygen } \\
\hline $\mathrm{Si}$ & 6.02 & 4.96 & 5.98 & 4.96 & 6.08 & 4.85 & 5.34 & 5.22 & 5.01 \\
\hline $\mathrm{Al}$ & 1.79 & 3.26 & 1.73 & 3.21 & 1.73 & 3.38 & 2.66 & 2.94 & 3.18 \\
\hline \multirow[t]{2}{*}{$\mathrm{Ti}$} & - & 0.11 & - & 0.04 & 0.10 & 0.03 & 0.04 & 0.06 & 0.07 \\
\hline & - & - & 0.09 & 0.01 & 0.02 & 0.01 & 0.03 & 0.02 & 0.01 \\
\hline $\mathrm{Fe}$ & 0.43 & 0.25 & 0.57 & 0.20 & 0.57 & 0.21 & 0.34 & 0.22 & 0.28 \\
\hline $\mathrm{Mn}$ & - & 0.03 & - & 0.03 & 0.05 & - & - & - & - \\
\hline $\mathrm{Mg}$ & 5.78 & 5.38 & 5.87 & 5.63 & 5.53 & 5.59 & 5.77 & 5.63 & 5.52 \\
\hline $\mathrm{Na}$ & 0.11 & 0.15 & 0.03 & 0.08 & 0.07 & 0.10 & 0.10 & 0.06 & 0.05 \\
\hline K & 1.96 & 1.44 & 1.74 & 1.35 & 1.79 & 1.26 & 1.63 & 1.59 & 1.54 \\
\hline \multirow[t]{2}{*}{$\mathrm{Ba}$} & 0.01 & 0.49 & 0.01 & 0.61 & - & 0.71 & 0.23 & 0.32 & 0.41 \\
\hline & 16.11 & 16.10 & 15.99 & 16.11 & 15.83 & 16.10 & 16.14 & 16.06 & 16.07 \\
\hline
\end{tabular}

$1-2,3-4,5-6$, rounded cores and euhedral overgrowths (02-09); discrete groundmass euhedral-to-subhedral crystals (02-22). 